\title{
МОНІТОРИНГОВІ ІНДИКАТОРИ ЕФЕКТИВНОСТІ ЗАКОНОДАВЧИХ АКТІВ
}

Постановка проблеми. Ефективність законодавчих актів залежить від таких основних факторів: взаємодія парламенту та уряду в правотворчій діяльності; якість законодавчих актів; ефективність реалізації та застосування права; рівень правосвідомості й правової культури.

Методичне забезпечення оцінювання ефективності законодавчих актів у процесі правового моніторингу має базуватися на використанні як загальних критеріїв, так і спеціальних показників, що показують параметри реалізації нормативних приписів.

Аналіз останніх досліджень та публікацій. Аналіз юридичної літератури 3 проблематики ефективності законодавчих актів показує, що змістовна сторона даного поняття все ще залишається досить проблематичною. Перші спроби сформувати дефініцію поняття «ефективність норм права» супроводжувались його ототожненням з поняттям «оптимальність», «обгрунтованість», «правильність» та «доцільність». Під ефективністю норм права розуміли їх погодження із потребами суспільного розвитку та закріплення оптимальних варіантів поведінки.

Американські вчені К. Волден і А. Вайсман розробили методику законодавчого оцінювання ефективності кожного члена Палати представників США (англ. The United States House of Representatives) з початку 1970-х по теперішній час. Проект оцінювання законодавчої ефективності забезпечує вченим, журналістам, представникам громадськості інформацію про успіхи членів сучасного Конгресу [2].

К. Волден, А. Вайсман і Д. Витмер виявили, що за певних обставин жінки є більш ефективними в законотворчості, ніж чоловіки. Підвищена ефективність залежить від партійного статусу сторін та від персональних характеристик. Партії, де жінки перебувають в меншості, постійно випереджають аналогічні партії чоловіків. Жінки були більш ефективними, ніж чоловіки, впродовж 1970-х і 1980-х, але менш ефективними, ніж чоловіки, в 1990-х і 2000-х роках. Дослідники також виявили, що ефективність чоловіків і жінок залежить від стадії законодавчого процесу та питань, які потребують правового врегулювання. Чоловіки значно успішніші в сільському господарстві, зовнішній торгівлі, міжнародних відносинах, науці та техніці. Жінки досягають чималих успіхів з питань, які стосуються жіночої сфери. 59,3\% законопроектів партії, де в більшості жінки, належать до категорії «злочинність» і «сім'я». Тоді як відповідна відсоткова частка партії, де в більшості чоловіки, становить $39,5 \%$ [2, с. 27-28].

Г. Падро, М. Джеймс і М. Снайдер дослідили, що законодавча ефективність пов'язана $з$ трьома факторами: 1) здібності та внутрішній потенціал законодавця; 2) освіта та особисті навички; 3) інституційна позиція законодавця: приналежність до партії або комітету, лідерство та членство в переважній партії [3, с. 2].

Мета дослідження полягає в обгрунтуванні та визначенні моніторингових індикаторів ефективності законодавчих актів.

Основні результати дослідження. Ефективність є одним з основних критеріїв для будь-якої раціональної поведінки. Беручи до уваги висновки праксеології, в науці права, вважається, що створення, застосування закону та його реалізація підлягають оцінюванню з точки зору залежності «засіб-мета». Сучасні теорії, які здійснюють спробу пояснити різні аспекти дії закону, як от, теорія раціональності зв'язку (Й. Габермас) або теорія розвиненого права (Н. Луман, Г. Теубнер) якоюсь мірою підірвали методологічну коректність цієї формули. Зауважено недолік суто інструментального підходу, який, у крайніх випадках, $є$ «наївним інструменталізмом». Розкриваючи один з аспектів даного питання, 
Г. Теубнер вичерпно вказав на те, що закон, не маючи шансів поєднання всіх супротивних інтересів і цінностей в одній системі, має створювати відповідні механізми зв'язку між окремими підсистемами, що забезпечують їх функціонування, попри відмінності представлених переваг [1].

Л. Іванова визначила ефективність права як відношення між фактично досягнутим, дійсним результатом і тією метою, для досягнення якої були прийняті відповідні норми права. Згідно з окресленою позицією, до змісту даного поняття не відноситься обов'язковість наявності позитивного результату та його максимальний ступінь. Обгрунтовується, що ефективність може бути негативною (зі знаком мінус) та виражатися в різній мірі (низькій, середній, високій) [4, с. 20].

Разом із розширенням сфери застосування поняття «ефективність» постала необхідність узагальнити його зміст. М. Андрющенко, аналізуючи практику використання поняття «ефективність», дійшов висновку, що ефективність - це міра певної можливості, яка пов'язана $з$ метою людини реалізувати ідею [5].

Отже, ефективність - це характеристика об’єктивації та конструктивної реалізації такого кількісного співвідношення як «ціль - теоретична можливість», «теоретична можливість - норма» [6, с. 35].

Процес створення норм права має юридичний характер, що зумовлює необхідність правової регламентації його механізмів. Відсутність норм права в цій системі нічим не можна заповнити або замінити. В результаті, сама правотворча діяльність без механізмів видається неможливою. Тому можна погодитися з точкою зору білоруського вченого С. Жолнеровича в тому, що зміст принципу регламентованості, по суті, розкриває залежність правотворчої діяльності від наявності нормативних регуляторів, що ії забезпечують [7, с. 134], важлива роль серед яких належить нормам права, які класифікуються на певні види.

О. Томкіна здійснила класифікацію сучасної практики здійснення оцінювання ефективності актів Кабінету Міністрів України на види за критеріями: час проведення (попередня та наступна); суб'єкти здійснення (соціальна, наукова, правова, фахова) [8, с. 18].

Показниками найбільшої ефективності нормативних актів Кабінету Міністрів України є: якість; наявність реально визначених об'ємів і джерел матеріально-фінансового забезпечення, реального механізму юридичного забезпечення впровадження актів у повсякденну практику; висока організація та професійна кваліфікація спеціалістів, які здійснюють контроль за виконанням актів, а також безпосередніх їх виконавців у системі органів виконавчої влади; постійно дієвий соціологічний моніторинг громадської думки щодо виданих актів Кабінету Міністрів України; якість правозастосовної діяльності та правомірність поведінки безпосередніх учасників урегульованих суспільних відносин; високий рівень правової культури громадян, колективних суб’єктів, суспільства [8, с. 18-19].

Одним зі стратегічних завдань механізму взаємодії парламенту та уряду є їх тісна співпраця в правотворчій діяльності. Для того, щоб оцінити рівень реалізації права, необхідно проаналізувати кількість прийнятих та відхилених законопроектів Верховною Радою, що були внесені урядом.

За перший рік роботи Парламентом VIII скликання було розглянуто майже третину (28\%) від усіх зареєстрованих законопроектів та проектів постанов ВРУ - 1344 нормативних актів. Стали законами 765 законодавчих ініціатив, що склало 16\% від загальної кількості зареєстрованих у ВРУ проектів нормативних документів і 57 \% від числа розглянутих у Раді за цей час законопроектів. 3 усіх 765 прийнятих документів 597 (78\%) було ініційовано депутатами, 110 (14\%) КМУ та 58 (8\%) - Президентом України. 85\% законодавчих ініціатив Президента (58 з 68 документів), внесених до Парламенту, були підтримані депутатами та стали Законами.

Громадянська мережа ОПОРА в рамках Програми USAID «РАДА: підзвітність, відповідальність, демократичне парламентське представництво» впродовж 2016 року формувала рейтинги 105 депутатів, діяльність яких моніторила та опубліковувала у розділі «Рейтинги» сайту РАДА. Щомісячні показники оцінювання та місце у рейтингу кожного зі 105 народних депутатів демонструвалися у їхніх профайлах [9].

Індикаторами моніторингу законодавчої активності народних депутатів України та їх активності у виборчому окрузі стали: 1) відвідуваність комітетів; 2) відвідуваність пленарних засідань; 3) пропуск пленарних засідань; 4) кількість зареєстрованих постанов; 5) кількість зареєстрованих законопроектів; 6) кількість законопроектів щодо проблем округу; 7) кількість законопроектів, що стосуються питань виборчої програми; 8) кількість запитів; 9) кількість запитів щодо проблем округу; 10) кількість сутнісних виступів; 11) активність в окрузі/області: кількість приймалень за межами округу [9]. 
Наведена вище методика моніторингового оцінювання законодавчої ефективності народних депутатів $є$ суспільно корисною ініціативою, яку аж ніяк не можна зарахувати до правової. Методика однобічно враховує тільки кількісні показники. 3 огляду на зазначене, вбачаємо за доцільне доповнити моніторингове оцінювання техніко-технологічними показниками якості та ефективності норм права. Без сумніву, формування рейтингу за кількісними та якісними показниками стимулюватиме народних депутатів України до більшої продуктивності, допомагатиме виявити недоліки у законопроектній роботі.

Низька якість та реалізація законодавчих актів $є$ чи не основною причиною відсутності позитивних характеристик. Основна проблематичність ефективності реалізації права до того ж полягає в тому, що в Україні діє безліч підзаконних актів. Відзначимо, що якість підзаконних актів і якість правореалізації загалом перебуває у залежності від якості законодавчих актів. Прийняття підзаконного акта з метою виконання неякісного закону лише провокує погіршення ефективності права. Через те, що підзаконний акт видається врозріз з положеннями закону, навіть якщо це спрямовано на виправлення в ньому помилок і неточностей, він стає незаконним, а це впливає на його неефективність.

Теорія права вивчає закономірності ефективної правореалізації та виокремлює форми правореалізації. Ефективність правореалізації залежить від впливу механізму реалізації права. Кожна форма механізму містить різну кількість елементів у своїй структурі, що збільшує ризик збою у роботі всього механізму.

Не менш суттєвим індикатором, 3 точки зору якого оцінюється ефективність реалізації законодавчих актів, є забезпечення суб'єктів правореалізації інформаційними даними. Щоб точно й правильно використовувати, дотримуватись та застосовувати закон всі суб'єкти індивідуальної або колективної правореалізації потребують достатньої кількості інформації про стан правового регулювання суспільних відносин.

Показник якості роботи органу, який здійснює реалізацію права, залежить від: стану управління; структури органу влади й організованості його діяльності; науковості організації праці правозастосовувачів; чіткості диференціювання функцій, компетенцій, злагодженості та скоординованості всіх ланок системи органів реалізації права; мікроклімату, в якому відбувається правозастосування. Багато залежить ще й від суб'єктивних якостей правозастосовувачів, до яких можна зарахувати: рівень знання права, рівень правосвідомості, професійну етику, авторитет, досвід, шляхетні моральні якості, загальний культурний рівень; матеріально-технічне забезпечення процесу правореалізації тощо [10, с. 173].

На значущості ролі працівників органів, які здійснюють правореалізацію («правового персоналу»), акцентував увагу німецький соціолог, економіст і правознавець Макс Вебер [11, с. 23].

Узагальнюючи наведений матеріал, можемо констатувати, що для здійснення моніторингу потрібні стабільні установки з виявлення динаміки вже прийнятих і чинних законодавчих актів. Вiдомо, що реєстрація таких актів у системі Міністерства юстиції України не дає повної картини. Не всі прийняті акти реєструються, і досить складно простежити загальну кількість опублікованих актів. Певна річ, для проведення моніторингу необхідні не тільки параметри обліку, але й такі показники, які допоможуть врахувати всі операції з уже прийнятим і чинним актом.

Висновки. Загальні індикатори ефективності реалізації законодавчих актів визначаються на етапі планування правового моніторингу. Показники уточнюються в результаті проведення правового моніторингу стосовно до сутності конкретних суспільних відносин, які виступають об' єктом нормативного регулювання. Крім того, оцінювання ефективності правової дії законодавчих актів має здійснюватися за низкою галузевих показників, які ілюструють специфіку нормотворчої та правозастосовної діяльності в оцінюваній сфері (моніторинг, що виконується під час офіційного тлумачення норм права державними органами та посадовими особами на етапі правозастосування).

Самостійного значення набувають індикатори оцінювання ефективності чинних законодавчих актів. Тут, як видається, повинні бути дві групи індикаторів. Перша звернена до системи законодавчих актів. За їі допомогою оцінюється повнота, своєчасність, законність, погодження акта 3 компетенцією органу, який його видає, законність включення акта в систему законодавчих актів. Друга група індикаторів відноситься до показників, що характеризують результати правозастосування та виконання законодавчих актів з точки зору їх значення для отримання соціально значущого результату в різних секторах, галузях, підгалузях суспільних відносин. 


\section{Список використаних джерел}

1. Kmieciak Z. Podstawy teoretyczne badania skuteczności regulacji prawnej jawności i jej ograniczec. URL: www. ksiegarnia.beck.pl/.../ jawnosc_i jej_ograniczenia_fragment.pdf (data odwoiania: 20.04.2018).

2. Volden C., Wiseman A. Legislative Effectiveness in the United States Congress: The Lawmakers. - Cambridge: Cambridge University Press, 2014. - 260 p.

3. Padry G., James M., Snyder M. Legislative Effectiveness \& Legislative Life / G. Padry, M. James, M. Snyder // Working Paper 04-28 July 2004. Cambridge: Massachusetts Institute of Technology, Department of Economics, 2004. - 41 p.

4. Иванова Л. А. Определение эффективности нормативных актов в процессе правового мониторинга : автореф. дис. ... канд. юрид. наук: 12.00.01; НОУ ВПО «Международ. юрид. ин-т». Москва, 2011. - 24 с.

5. Эффективность норм права, эффективность права, эффективность актов применения. - URL: library.by/.../ referat_readme.php?...id (дата посещения: 10.03.2019).

6. Онищук И. И. Мониторинговое оценивание эффективности взаимодействия Верховной Рады и Кабинета Министров Украины в законотворческом процессе / И. И. Онищук // Сацыяльна-эканамічныя і прававыя даследаванні. - 2016. - №3. - С. 33-41.

7. Жаўняровіч С. А. Прынцыпы заканадаўчага працэсу / С. А. Жаўняровіч // Веснік ГрДУ. Серыя 1. 2000. - №2. C. 127-136.

8. Томкіна О. О. Акти Кабінету Міністрів України: теоретичні засади видання та реалізації : автореф. дис. ... канд. юрид. наук: 12.00.07; Київський нац. екон. ун-т. - К., 2005. - 21 с.

9. Моніторинговий проект ОПОРИ-2016: аналіз діяльності 105 депутатів-мажоритарників. URL: https:// rada.oporaua.org/dorogi-deputati/novini/8802-monitorynhovyi-proekt-opory-robota-deputativ-mazhorytarnykivu-okruhakh-2016 (дата звернення: 01.05.2018).

10. Завадская Л. Н. Механизм реализации права / Л. Н. Завадская. - Москва : Норма, 1999. - 238 с.

11. Кудрявиев В. Н., Казимирчук В. П. Современная социология права : учеб. для юрид. фак. и ин-тов. - М. : Юристь, 1995. - 328 с.

\section{References}

1. Kmieciak Z. Podstawy teoretyczne badania skuteczności regulacji prawnej jawności i jej ograniczec. URL: www. ksiegarnia.beck.pl/.../jawnosc_i_jej_ograniczenia_fragment.pdf (data odwoiania: 20.04.2018).

2. Volden C., Wiseman A. Legislative Effectiveness in the United States Congress: The Lawmakers. - Cambridge: Cambridge University Press, 2014. - 260 p.

3. Padry G., James M., Snyder M. Legislative Effectiveness \& Legislative Life / G. Padry, M. James, M. Snyder // Working Paper 04-28 July 2004. Cambridge: Massachusetts Institute of Technology, Department of Economics, 2004. - 41 p.

4. Ivanova L. A. Opredelenie jeffektivnosti normativnyh aktov v processe pravovogo monitoringa: avtoref. dis. ... kand. jurid. nauk: 12.00.01; NOU VPO «Mezhdunarod. jurid. in-t». Moskva, 2011. - 24 s.

5. Jeffektivnost' norm prava, jeffektivnost' prava, jeffektivnost' aktov primenenija. - URL: library.by/.../referat_readme. php?...id (data poseshhenija: 10.03.2019).

6. Onishhuk I. I. Monitoringovoe ocenivanie jeffektivnosti vzaimodejstvija Verhovnoj Rady i Kabineta Ministrov Ukrainy v zakonotvorcheskom processe / I. I. Onishhuk // Sacyjal'na-jekanamichnyja i pravavyja dacledavanni. 2016. - №3. - S. 33-41.

7. Zhay̆njarovich S. A. Pryncypy zakanaday̆chaga pracjesu / S. A. Zhay̆njarovich // Vesnik GrDU. Seryja 1. 2000. №2. - S. 127-136.

8. Tomkina $O$. O. Akty Kabinetu Ministriv Ukrai'ny: teoretychni zasady vydannja ta realizacii': avtoref. dys. ... kand. juryd. nauk: 12.00.07; Kyi'vs'kyj nac. ekon. un-t. Kyi'v, 2005. - 21 s.

9. Monitoringovij proekt OPORI-2016: analiz dijal'nosti 105 deputativ-mazhoritarnikiv. URL: https://rada.oporaua.org/ dorogi-deputati/novini/8802-monitorynhovyi-proekt-opory-robota-deputativ-mazhorytarnykiv-u-okruhakh-2016 (data zvernennja: 01.05.2018).

10. Zavadskaja L. N. Mehanizm realizacii prava / L. N. Zavadskaja. - Moskva: Norma, 1999. - 238 s.

11. Kudrjavcev V. N., Kazimirchuk V. P. Sovremennaja sociologija prava: ucheb. dlja jurid. fak. i in-tov. - Moskva: Jurist\#, 1995. - $328 \mathrm{~s}$.

\section{Онищук I. I. Моніторингові індикатори ефективності законодавчих актів}

Правовий моніторинг позначається на динаміці права, супроводжує елементи механізму правового регулювання: від формування нормативної бази до забезпечення законності й правопорядку. Головною метою правового моніторингу є підвищити ефективність правотворчої діяльності та функціонування механізму правового регулювання. Згідно з широким підходом до розуміння сутності правового моніторингу його загальним об'єктом на національному рівні виступає правова система країни, усі правові явища у межах кордонів держави, усі елементи механізму правового регулювання, а згідно з вузьким підходом - система законодавчих актів.

Ефективність механізму правового регулювання - це властивість процесу реалізації права, а якість $\epsilon$ лише необхідною умовою результативної дії права. Соціальний аспект якості законодавчих актів пов'язаний зі змістом, 
а юридичний - $з$ формою. Внутрішнім чинником, що обумовлює ефективність будь-якого законодавчого акта, є соціальна цінність, яка характеризує його якість.

Ключові слова: правовий моніторинг, індикатори, правова експертиза, правовий конфлікт, правова колізія, ефективність законодавчих актів, правове регулювання, правове оцінювання.

\section{Onyshchuk I. I. Monitoring indicators of the efficiency of legislative acts}

Legal monitoring affects the dynamics of law, accompanied by elements of the mechanism of legal regulation: from the formation of the regulatory framework to ensure law and order. The main objective of legal monitoring is to increase the efficiency of law-making activity and the functioning of the legal regulation mechanism. According to the broad approach to understanding the essence of legal monitoring, its general object at the national level is the legal system of the country, all legal phenomena within the boundaries of the state, all elements of the mechanism of legal regulation, and according to the narrow approach - the system of legislative acts.

The effectiveness of the legal regulation mechanism is a property of the process of implementing law, and quality is only a necessary condition for the effective action of law. The social aspect of the quality of legislative acts is related to content, and legal - with the form. The internal factor that determines the effectiveness of any legislative act is the social value that characterizes its quality.

Key words: legal monitoring, indicators, legal expertise, legal conflict, legal gap, efficiency of legislative acts, legal regulation, legislative evaluation.

DOI: 10.33.66.3/2524-017X-2019-10-73-77

УДК: 340.134 (045)

Н. М. Пархоменко, доктор юридичних наук, професор, вчений секретар Інституту держави і права ім. В. М. Корецького НАН України

\section{НАУКОВО-ПРАВОВА ЕКСПЕРТИЗА: ДОКТРИНАЛЬНІ ТА ЗАКОНОДАВЧІ ВИМІРИ}

Постановка проблеми. Якісний стан чинного законодавства України характеризується недосконалістю, що знаходить прояв у колізійності змісту, прогальності, невизначеності та постійною потребою тлумачення його окремих положень. Зазначене здійснює деструктивний вплив на регулювання суспільних відносин та перешкоджає реалізації прав і свобод громадян. Одним із засобів подолання цієї проблеми є з'ясування та роз'яснення сутності і змісту норм права, тобто його тлумачення.

Нерідко тлумачення потребує застосування закону в часі щодо конкретних правовідносин у зв'язку зі зміною законодавства або при триваючих правовідносинах. Необхідність роз'яснення законодавства для суду, правоохоронних органів, для будь-яких суб'єктів права також зумовлена особливостями правового регулювання окремих сфер діяльності [1, с. 409].

Аналіз останніх досліджень та публікацій. Проблема тлумачення норм права не нова і з'явилась 3 появою права. Відповідно наразі в юридичній науці існують як фундаментальні напрацювання, так і пошукові роботи, викликані постійним розвитком суспільних відносин і об'єктивною потребою їх врегулювання. Зокрема, серед дослідників, які здійснили загальнотеоретичне з'ясування сутності, природи, змісту, класифікації та ін. проблем тлумачення, необхідно назвати Ю. Л Власова, А. Г. Зайця, А. В. Зубенко, В. В. Гончарова, Н. Я. Лепіш, П. М. Рабіновича, Н. Д. Слотвінську, В. Я. Тація, Ю. Тодику та ін. В межах окремих галузей права проблеми тлумачення норм права були предметом розгляду М. В. Котенка, С. О. Звєрєва, О. В. Капліна, Т. В. Комарової та ін. При цьому, як правило, предметом дослідження було офіційне тлумачення норм права та його результати - акти тлумачення. Лише останнім часом з'явились роботи, присвячені аналізу неофіційного тлумачення загалом та доктринального тлумачення зокрема. Серед актів доктринального тлумачення окреме місце займають висновки науково-правової експертизи. Інтерес до цієї проблематики посилився 